\title{
A CONTRIBUTION TO THE GEOLOGY OF VITI LEVU, FIJI.
}

By W. G. Woolnough, D.Sc., F.(T.S., Assistant Lecturer in Geology and Mineralogx, University of Sydney.

Contents.

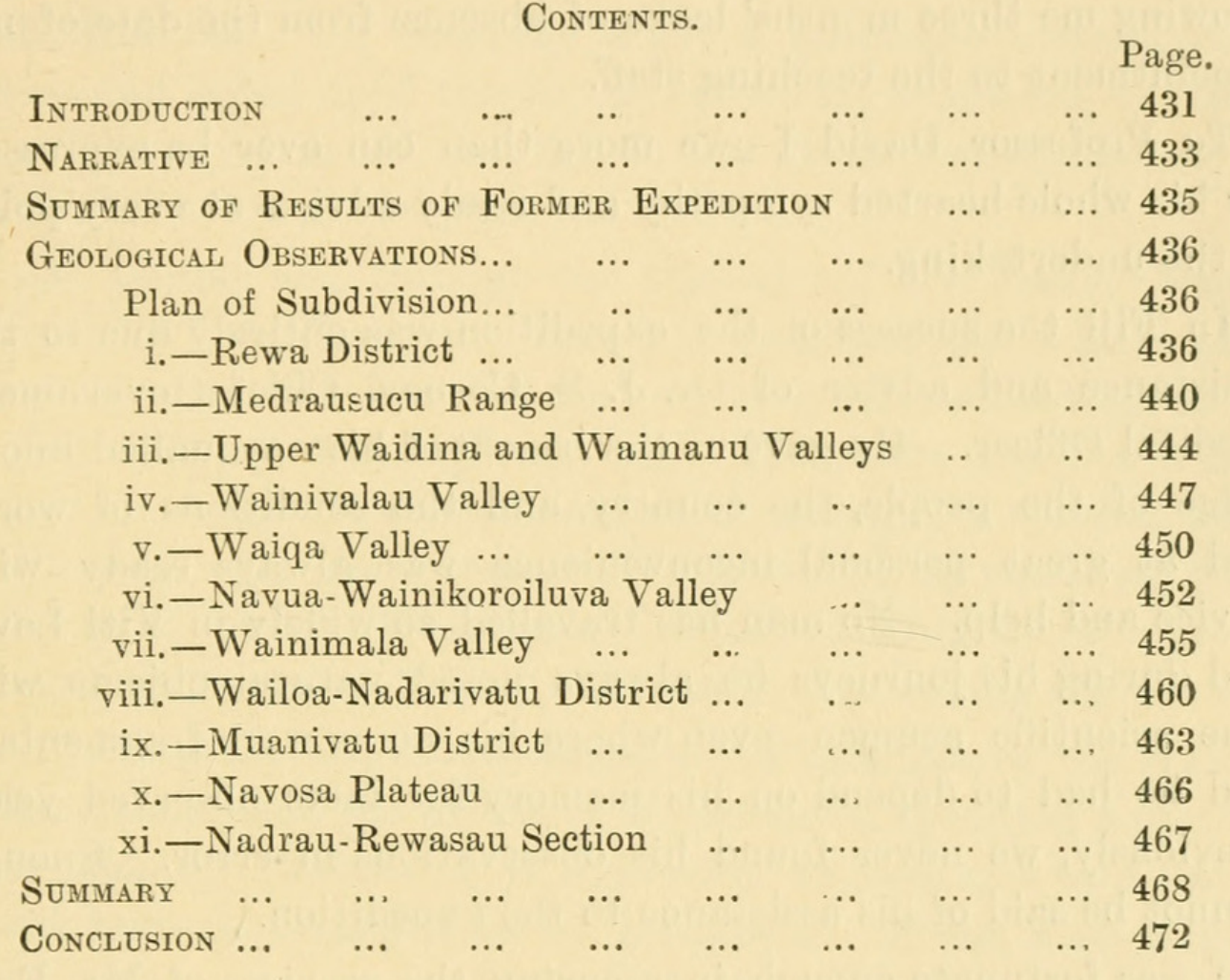

\section{INTRODUCTION.}

In January and February, 1901, at the suggestion of Professor J. W. Judd, F.R.S., and with Professor David's permission, I spent about six weeks in exploring geologically the central portion of Viti Levu, the main island of the Fiji Group. The results of that expedition were published in the Proceedings of this Society (Vol. xxviii.1903,pp.457-496, 500-540, Plates xxii.-xxxvi.).

Note.-I have given all names as they are spelt in Fiji because of the difficulty I have had in getting natives to locate places if the spelling is Anglicised. The language is phonetic; the vowels have the French values, double vowels are true diphthongs. Of the consonants $b=m b, c=$ th (as in that), $d=n d, g=n g$ (soft), $q=n g-g$ (hard). The accent in simple words is usually on the penultimate, sometimes on the last syllable. 
With the assistance of Professor Judd, a grant of seventy pounds was obtained from the Royal Society of London in 1903, and a further grant of eighty pounds in 1904. This liberality enabled me to carry out a much longer and better equipped expedition during the early part of 1905 , when I was able to spend almost three months in central Viti Levu. My best thanks are also due to the Senate of the University of Sydney for allowing me three months' leave of absence from the date of my appointment to the teaching staff.

To Professor David I owe more than can ever be expressed for his whole-hearted sympathy and ready advice at every point of the undertaking.

In Fiji the success of the expedition was entirely due to the assistance and advice of Dr. J. B. Corney, Chief Government Medical Officer. He gave us the benefit of his unequalled knowledge of the people, the country, and the conditions of work; and at great personal inconvenience was always ready with advice and help. No man has travelled so widely in Viti Levu, and during his journeys he always noted natural objects with true scientific acumen; even where his notes were fragmentary and he had to depend on his memory for facts observed years previously, we never found his observations in error. Enough cannot be said of his assistance to the expedition.

I was fortunate enough in securing the services of Mr. E. J. Goddard, B.A., B.Sc., Junior Demonstrator in Biology, University of Sydney, as assistant. Throughout all the difficulties and dangers of the trip he proved himself a loyal and courageous companion, and I desire to express to him my thanks.

Through the good offices of Mr. Thomas Steel, F.L.S., the Directors of the Colonial Sugar Refining Company were good enough to give general directions to all their managers in Fiji to help me where possible. This request was most liberally interpreted, and to all concerned my grateful thanks are hereby rendered.

Other acknowledgments will be made below. 


\section{Narrative.}

Leaving Suva on 6th January, 1905, we proceeded up the Rewa River to Nausori. Mr. R. Gemmel Smith, general manager for Fiji of the Colonial Sugar Refining Company, extended his hospitality and afterwards very kindly allowed the expedition to travel to Bau Levu by the stern-wheel river-boat belonging to the Company. At Bau Levu we were hospitably entertained by Mr. Freeman. On Saturday night a hurricane commenced to blow, and lasted until the middle of Sunday afternoon, but fortunately heavy rain did not fall in the Rewa Valley, so that the river did not come down in heavy flood.

Dr. Corney had, through the kindness of Mr. Joske, Commissioner for Colo East, etc., been able to arrange for a large canoe to meet us at Bau Levu, so that we were able to start up stream again early on Monday morning. The canoe was not able to carry all our goods, so that we had to arrange for another one to follow us with the excess. We travelled by canoe as far as Naivucini on the Wainimala. While waiting for the second canoe, we ascended Nacau, a mountain overlooking the town.

We then travelled southwards to Nabukaluka, on the Waidina River, and made the ascent of Nabukelevu, spending a night on the summit. Returning to Naivucini, we were met by a train of pack bullocks arranged for by Mr. Joske. These, with a party of native porters, carried our goods through a long day's journey to Narokorokoyawa on the Upper Wainamala, at which town we had decided to make our headquarters.

A few days were spent working in the neighbourhood of the town. On 23rd January we set out to cross the high plateau of Navosa. This took us two days of exceptionally hard travelling. The climb on to the plateau is about 2000 feet, and the surface of the plateau is simply a morass. After floundering through this for miles, we were overtaken by a heavy thunderstorm, converting the streams into raging torrents which it was impossible to cross. We were delayed for a considerable time waiting for one of these to subside, and, after crossing it, reached the western 
edge of the plateau, overlooking the valley of the Sigatoka River just as night was falling. After descending about 1500 feet over slippery soapstone, we found the Sigatoka in moderate flood, and were unable for some time to find a means of rounding a precipitous bluff and reaching the town of Namoli. We finally accomplished this by wading through the flood-water, and arrived in the town after seventeen hours' heavy travelling. We travelled down the river to Natuatuacoko and returned to Narokorokoyawa via Waibasaga, Vunatoto, Naduta and Korolevaleva.

On 30th January I started alone to revisit the Waidina Valley, leaving Mr. Goddard to carry on his biological work at Narokorokoyawa. I was forced to return to Suva to obtain boots, but returned to Narokorokoyawa by way of the Wainivalau Valley, crossing a track which has not, I believe, been traversed by another white man.

On February 10th I left Narokorokoyawa for Nadarivatu via Vatuvula, Nubumakita and Nasoqo, and arrived there 15th February. Mr. Goddard and I left again, in company, on 18th, and reached Nadrau on Upper Sigatoka. Thence we proceeded to Vuniwaiwaivula at the junction of the Wailoa and Rewasau Rivers, and went on to Udu at the junction of the Wailoa and Wainimala Rivers. Here we were delayed for a day by a heavy flood, and were enabled to reach our headquarters next day only through the marvellous resourcefulness of our head man Pita Caginicolo.

We returned to Suva by the same route traversed on the up journey. We were again indebted to Mr. Freeman for hospitality, and also for the loan of his boat and crew to take us to Nausori, where we caught the steamer for Suva.

On arriving at the capital we found that there was no news of the "Pilbarra," and it was surmised that she had broken down. I therefore cabled to the Registrar of the University of Sydney requesting an extension of leave for an extra fortnight. This having been granted, I set out with Mr. C. A. Holmes, Mr. Goddard being ill, to attempt the ascent of Korobasabasaga in the hope of gaining considerable information from the bird's-eye 
view obtainable from its summit. As we could not obtain guides, we were forced to give up the attempt. We therefore followed the Waidina River to its source, crossed into the Wainikoroiluva Valley, and followed it and the main Navua River to Navua, thence returning to Suva.

With a longer time at my disposal, a much improved equipment, and a fair working knowledge of the language, and with the results of my former expedition as a basis upon which to work, I have been able to add considerably to the work done previously. Even now I can claim only that a general idea of the geological structure of Viti Levu has been obtained; the salient facts are correct, but the details are subject to modification by future observations. It is only natural that my earlier work requires extensive revision. On the whole, the results of my second exploration of Viti Levu have confirmed the main conclusions formed by me after my first exploration there, but there are several very important alterations which must be made in it. These will be noted in their proper place.

\section{Summary of Results of Previous Expedition.}

In my previous paper* I showed that while the main bulk of the island of Viti Levu is built up of andesitic and basaltic lavas and tuffs, "soapstones," and upraised coral reefs, there are nevertheless extensive areas of granitic and slaty rocks. Granitic and slaty rocks being practically confined to continental areas, I sought to show reason why Fiji should be considered as continental in origin.

The continental rocks were met with in the very centre of the island, extending from Wainiveidro on the upper Wainikoroiluva River to near Udu on the upper Wainimala River, a distance of upwards of thirty miles by track. Slaty rocks were met with near Namoli (called in error Nalaba) on the Sigatoka River, and examination of the river gravels of the island indicated a wide range of distribution for similar rocks.

* These Proceedings, 1903, Vol. xxviii. pp.457-496, 500-540, Plates xxii.xxxvi. 
Fossiliferous limestones of Middle Tertiary Age were met with at Walu Bay, Suva, and at Tawaleka, Sigatoka River. An immense mass of dense white limestone occurs at Naqalimare, on the Sigatoka, but has yielded no fossils.

The volcanic rocks were divided into a southern andesitic series and a northern basaltic series, each associated with tuffs and agglomerates, and giving rise to extremely rugged mountainous country.

The "soapstone" is an almost ubiquitous rock. As its name implies, it is a fine-grained, unctuous roek. It is stratified, the bedding generaliy being nearly or quite horizontal. I believe it to be a redistributed volcanic tuff deposited under marine conditions. At Nasoqo it has yielded marine fossils and waterworn boulders of granite, and at Nadrau marine fossils. The former place stands at an altitude of over 800 feet above sea-level, and the latter place at over 1200 feet, so that we have evidence of elevation of the land to the extent of at least 1200 feet during Cainozoic time.

I failed to find any conclusive evidence of folding or faulting connected with the movements which, I assumed, had isolated Fiji from the continental areas to the west, but thought that there was possible evidence of a fault at Nadarivatu.

Geological Observations.-Plan of subdivision.

For convenience I shall divide the area examined into several geographical districts, and describe these in order. These districts are indicated by numerals on the sketch plan (fig.1).

It must be understood that this division is one of convenience only and has nothing whatever to do with the official partition of the island into provinces and districts.

i.-Rewa District (including the Lower Wainimala, Waidina, and Waimanu Rivers).

The Rewa Delta and the lower Wainimala were described to some extent in my former paper. At the upper end of the steamer channel through the mangrove belt of the delta, where the channel joins the main river, it was noticed that a bar of reef limestone was being blown up to deepen the channel. I 
could not obtain specimens, but judging from appearances it consists of the ordinary reef material; it was situated at a depth of about three feet below low-water mark. This point is about three miles from the present edge of the mud flat and five miles

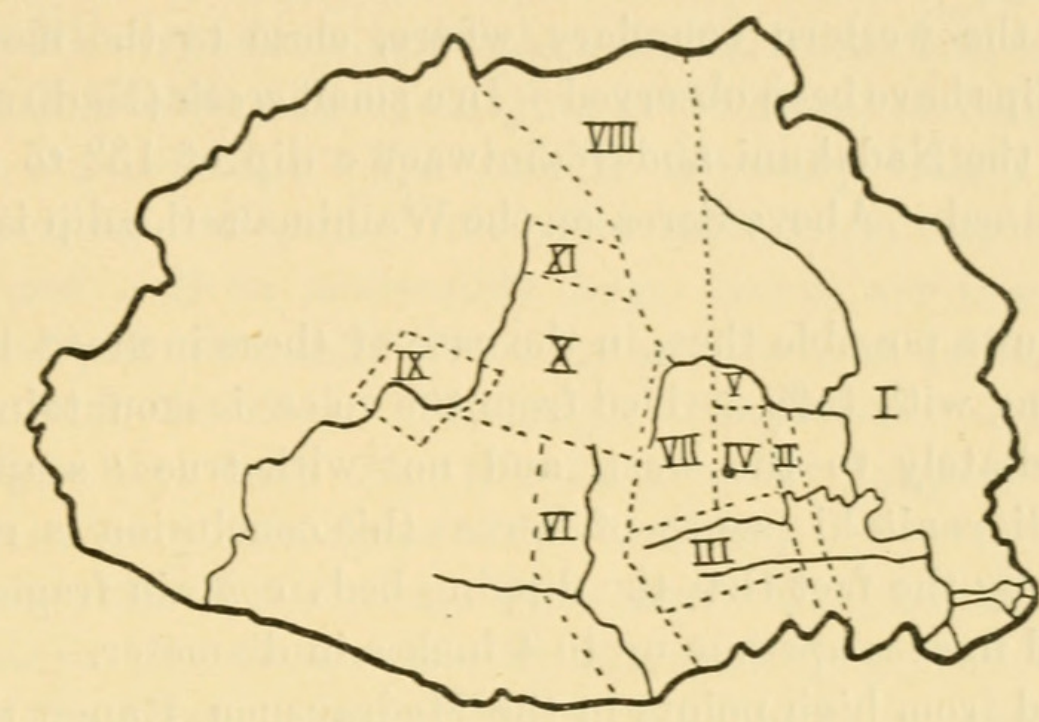

Fig.1.-Index Map of Viti Levu showing the relative positions, but not the absolute boundaries of the districts discussed in this paper. i.The Rewa Area, ii.The Medrausucu Range, iii.Upper Waidina and Waimanu Valleys, iv.Wainivalau Valley, v.Waiqa Valley, vi.Navua-Wainikoroiluva Valley, vii. Wainimala Valley, viii. Wailoa-Nadarivatu District, ix.Muanivatu District, ix.Navosa Plateau.

from the existing reef of Nukulau Passage. Its presence proves that there has been a considerable seaward advance of the river sediments, and that, for a long time, present conditions of level have not been altered to any great extent, a fact borne out by an examination of river history in the upper portions of the valley.

The high level soapstone near Naduruloulou noted before* proves to be of great interest and importance. There is evidence that there formerly extended over the whole of the area now occupied by the upper portion of the delta a continuous sheet of estuarine deposits with lignitic bands. These are now represented by isolated hills about Nausori, and more continuous areas higher up in the neighbourhood of Naduruloulou. They rise to a height of about 100 feet above the surface of the present river flats, indicating an elevation of this portion of the island since the beds were deposited. Passing northwards and westwards

\footnotetext{
* Loc. cit. p. 464 .
} 
the level of these soapstone hills gradually rises until an elevation of from 300 to 500 feet is attained. Everywhere that I have examined sections of this formation in the district under consideration, I have found the beds to lie almost level, except towards the-western boundary, where, close to the mountains, steeper dips have been observed. In a small creek (Nadirubasaga) between the Nadakuni and Wainiwaqa a dip of $15^{\circ}$ to the east was obtained. Above Serea on the Wainimala the dip is E.N.E. at $8^{\circ}$.

It is quite possible that, in the case of these inclined beds, we are dealing with tuffs derived from the volcanic mountains which lie immediately to the west, and not with true "soapstones." Near Qelidranitaki (south of Serea) this conclusion is rendered probable by the fact that the dipping beds contain fragments of older and finer soapstone up to 4 inches in diameter.

Viewed from high points in the Medrausucu Range the area occupied by the level-bedded soapstones appears almost perfectly level, and seems to extend in an unbroken plain right away to the east coast of the island. There are, I believe, a number of deep, narrow river valleys east of the Rewa; their positions are, however, uncharted.

The area is a plain of marine accumulation uplifted with very little disturbance of the bedding. The fact that the track going south from Serea rises by a series of gentle slopes and falls by a series of steep scarps, suggests a gentle northerly dip, but lack of rock exposures and dense tropical jungle prevent direct observation.

A few isolated points rise above the general level of the plain. It is possible that these may represent the residuals of an older level at an elevation between 700 and 1,000 feet, but data are wanting.

With the elevation of the soapstone plain the rivers entered upon a cañon cycle. The rocks, consisting as they do of alternate relatively hard and soft beds of soapstone, produce a structure favourable to rapid recession of the streams. Even so, the fact that the first trace of a rapid in the Wainibuka is at least 30 
miles from the top of the delta, and over 40 from the sea, proves that the elevation is not an extremely recent one. The evidence of the reef at the river mouth has already been commented on.

From Viria onwards the river valley becomes practically a gorge. No very extensive patches of alluvial are met with, and the soapstone cliffs rise to heights of 200 to 300 feet almost from the water's edge. The smaller tributary valleys do not enter the river "at grade" but yield cascades falling into the main stream. Even moderately large creeks are interrupted by picturesque waterfalls at no great distance above their junctions with the river. The larger tributaries are at grade. The small valleys have thus the character of hanging valleys, and indicate the youthfulness of the stream.

I followed the Wainibuka a little above the junction of the Wainimala in order to examine the nature of the gravels brought down by the former stream, but found that there were none. The natives informed me that this river is singularly destitute of gravel for a very considerable distance. This shows that the whole of the country drained by it is a continuation of the soapstone plain, uninterrupted by areas of volcanic or plutonic rock.

In the Wainimala, up to the town of Serea, level-bedded soapstones similar to those described above, form the banks, but, unlike the Wainibuka, there are extensive and varied gravels consisting of rock types met with in situ further to the west.

Above Serea strongly marked dips are encountered in the soapstones (vide p.438).

I searched carefully for fossils in all the soapstones, but found very few traces of macroscopic organisms. The lignified plant stems of Naduruloulou were referred to in my last paper. In addition to these, ill-defined plant fossils were found just above the first rapid of the Wainibuka.

In general character and in elevation these soapstones are comparable with those in Suva. If the rocks here are contemporaneous with those of Walu Bay near Suva, then we may form some idea of their age. In the latter case they are not newer than Pliocene, and may be Miocene. For topographic 
reasons $I$ am not inclined to believe the Rewa soapstones older than Pleistocene, though it is possible they may be as old as Pliocene. In the absence of further data the correlation of the Rewa soapstones with those of Walu Bay cannot be considered proved.

Nowhere in this area have basal beds of the soapstone series been observed, so that, in the absence of fossils, their stratigraphical relationships are obscure. In the deep creeks just east of the Medrausucu Range, the lowest rocks encountered are jointed andesites, but these are in all probability intrusive into the soapstones.

Summary of Section i.-The greater part of the area is covered by level-bedded "soapstone" containing traces of plant fossils and representing redistributed tuffs. These form an extensive plain, with an average elevation of some 300 feet. In the surface of this plain the rivers occupy cañon-like valleys. At the head of the Rewa Delta the high-level plain is broken into mesas with an altitude of about 100 feet. The delta is very extensive, and this, together with the occurrence of reef-limestone well within the mangrove belt, proves that there has been no notable change in sea-level for a considerable time. No solid rocks of any kind occur in situ anywhere in the region except just at the base of the Medrausucu Range.

\section{ii.-Medrausucu Range.}

I have taken the liberty of referring to this remarkable range of mountains by an abbreviation for the name of its two most prominent peaks, Medrau sucu basaga. The range is a most striking feature from all points of view. Its eastern face, as seen from the Rewa Plateau, is almost precipitous throughout its entire extent. It is strikingly linear in character, extending for many miles in a N.N.W.-S.S.E. direction. It stretches from the south coast a little west of Suva, to Nacau, a mountain just north of Naivucini, a town at the junction of the Wainimala and Wailase Rivers. At its southern end it is not sharply defined from a number of other mountain rìdges, 
which cross it more or less at right angles; but throughout the rest of its extent it presents a bold scarp to the east. On my former expedition I did not obtain a good view of this range, and my information led me to believe that the country lying to the west consisted of a high plateau; but, as shown below, this idea is incorrect. Running, as it does, almost meridionally, it cuts directly across the courses of a number of important east and west branches of the Rewa River, chief among which are the Waimanu, Waidina, and Wainivalau, in order from south to north. These emerge from the range through a magnificent series of water-gaps, which are well seen on a clear day from the high-level soapstone hills about Nausori. The chief peaks in the range are Namaku and Wainiwaqa, respectively south and north of the Waidina, Medrau sucu basaga (the Fijian equivalent for "The Paps," by which name this pair of hills is known to the British residents), Kororaqiqi, ${ }^{*}$ Ucikavukavu† and Namolaca, respectively south and north of the Wainivalau, Nariko and Nacau south and north of the Wailase. Nabukelevu, the "Great Yam Mound,"(spelt Buki Levu before) forms a narrow spur extending for two or three miles to the east of the main range.

The true structure of the range, suggested by these water-gaps, is not seen to advantage until viewed from the summit of one of the mountains twelve or fifteen miles to the west. From a point such as Uvuuvunidavui, the range is seen to be simply a wall of rock some 2000 feet in height, and not more than three or four miles in thickness at the base. Lying to the west of its central and northern sections is an extensive plain which will be described in detail later. On close examination the range is found to be built almost entirely of very coarse andesitic agglomerate. The boulders in it are generally of hypersthene andesite, with a base varying from glassy to pilotaxitic. $\ddagger$ Sometimes hypersthene

* Spelt Kororagigi in my former paper.

+ Spelt Kavukavu in my former paper.

† Former paper, loc. cit. pp.520-525. 
fails, and pseudomorphs of magnetite and augite after hornblende appear. Massive products of eruption are quite subordinate to fragmental ones, but numerous dykes and sheets or sills occur. One of the former, Devo,* has given rise to an imposing piece of scenery. In all instances these rocks are perfectly fresh, and have not suffered at all from orogenic processes.

The contrast in form and structure between this range and the Rewa Plateau, immediately to the eastward, is very striking. Soft soapstones run right up to the base of the range, but, at a very short distance within the gorge of the Wainivalau, the agglomerates rest upon granites and jointed rocks. The actual junction-line is obscured. The importance of this structure is discussed later (p.448).

The forms of the peaks of the range are very suggestive of a line of volcanic necks partially denuded. $\dagger$ Nacau, at the northern end of the range, has very strikingly the appearance of a crater rising 1230 feet from the level of the plain to the eastward. Its shape is crateriform, the highest point of the rim lying to the west. The northern portion of the rim, for about a quarter of its circumference, is broken down; and the central portion is occupied by a deep crateral hollow. The southern face exhibits a steep cliff formed by a subsidence of the outer crater-slopes on that side. The northern end of Nariko, facing it across the valley of the Wailase, exhibits a similar cliff; and the ridge joining the two and rising to a level of about 600 feet above the plain probably represents a sunken block.

The cliffs and eastern side of the ridge consist of andesite agglomerate, but the western side of the ridge is of diorite porphyry. The latter rock extends for some distance westward along the valley of the Waiqa River. It will be discussed in the description of that area.

* Former paper, p.467, plate xxiii., fig.4.

$\uparrow$ The high range of hills in the background in the view of Nabukelevu (former paper, platexxiv., fig.5) has no existence either in fact or upon my negative; it is a creation of the process engraver. The hills behind Nabukelevu were hidden in mist when the photograph was taken. 
The water-gaps mentioned above are not the only ones developed in the range. Between Ucikavukavu and Nariko there is another well marked one. It is not, however, occupied by a considerable stream. Close to Serea there enters the Wainimala Valley, a very considerable tributary valley whose bed is occupied by a long lagoon known as the Waieliu or "Former River." This heads towards the gap above-mentioned, and I have no doubt that we are dealing here with an instance of river-capture occurring within historic time. The "pirate" was certainly one of the headwater streams of the Wainivalau, possibly the Waisomo. That this is the case is rendered likely by the large volume of the Wainivalau in proportion to the size of its gorge, as compared with other rivers.

In addition to the main rivers crossing the line of this range, there are numerous smaller streams rising in it which have cut more or less deep notches, such as the Waibowa, rising just to the south of Nabukelevu, Waicevu north of the Wainivalau, Wainimase south of Serea, and several other still smaller creeks.

In the bed of the Waibowa pebbles of granite occur, but in the other minor streams crossed no such granitic material was observed. Pebbles of jointed and saussuritized trachyte, exactly similar to that described later, occur, thus showing that fairly ancient rocks occur within the reach of the east-flowing creeks.

The very great geological importance of this range of mountains will appear later.

$\mathrm{Sum}$ mary of Section ii.-The Medrausucu Range is a remarkable, linear, wall-like range of volcanic mountains stretching N.N.W.-S.S.E. a little to the west of the meridian of Suva. It is crossed by numerous large rivers which have cut great water-gaps in it, and are certainly antecedent streams. There is at least one important " air-gap," and it is highly probable that the river-capture originating this feature took place within historic time. The smaller streams are busily engaged notching the divide. All the topography suggests extreme youth. All the larger, and some of the smaller, streams have reached the 
foundation of ancient rocks, in part plutonic, lying below the volcanic material which builds the bulk of the range.

\section{iii.-Upper Waidina and Waimanu Rivers.}

A journey up the Waidina Valley has already been described, * and very little need be added here. The Great Dyke of Devo (Plate xxiii., fig.4 of my former paper) bears nearly north and south, $\uparrow$ and therefore about parallel to the general trend of the Medrausucu Range, on whose western flanks it occurs. It has a distinct underlie to the west.

The general direction of the Waidina Valley is about E.N.E. and W.S.W., that is at right angles to the line of weakness suggested by the trend of the Medrausucu Range. The valley is bounded on the south by a range of hills which have the appearance of a line of denuded volcanoes. It is a very common feature in orogenic processes that lines of weakness develop in the form of a nearly rectangular network; the case under discussion seems to conform to this general law. Another line of hills, in approximate parallelism with the river-valley, occurs on its northern side, in its upper course.

I stated in my former description of the Waidina Valley that the hot spring at Naseuvou rises through solid quartz diorite. $t$ This statement has to be corrected. The rock is really jointed andesite, the mistake having been caused by a transposition of specimens.

A small tributary, the Waimanu, enters the main stream on its left bank, just above the town of Nasirotu, and brings down abundant large boulders of quartz diorite, which rock must, therefore, occur in situ at no great distance to the north.

I ascertained that the Wainavadu, in which abundant and very large boulders of quartz diorite occur, rises beyond the north-

* Former paper, p.465.

+ Compass bearings in the volcanic parts of the island are often quite unreliable on account of the extraordinary local deviations.

‡ Former paper, p.468. 
eastern end of Korobasabasaga at a place called Mataicicia. It thus drains part of the area to the south-west of the Wainivalau Valley, and proves a southward and westward extension of the crystalline rocks met with in situ in the latter stream. Judging from the size and abrasion of the boulders, I judge that the granitic rocks occur in situ some ten or fifteen miles (by river) north of Delai Lasakau on the Waidina.

There is little to add with regard to the upper portion of the Waidina Valley with the exception of some rather striking topographic details. There is a decided suggestion in places of block-mountain formation; the crests of the blocks have a uniform gentle slope of about $10^{\circ}$ in a southerly direction. Fairly considerable streams continue to within a mile or thereabouts of the water-parting between the Waidina and Wainikoroiluva.* They then bend north and south, and so flow parallel to the divide. The latter is itself parallel to the line of weakness manifested in the Medrausucu Range, and, like it, is a linear range of andesitic agglomerates. The most striking feature is, however, the nature of the pass. This has a level floor, about two miles wide, bounded north and south by the towering cliff-faces of Nairibiribi and Natabuwaitui. These answer in every respect to the cliffs bounding the gorges in the Medrausucu Range, through which issue the main streams flowing eastward. The resemblance is so striking that there can be little doubt, I think, that these cliffs mark a comparatively recent water-gap, and indicate a very profound disturbance of the drainage-systems of this part of the island in late geological time.

An examination of the map (Plate xii.) will show that the trend of the Main Navua Valley is markedly collinear with that of the Waidina River. Not only is it collinear, but it is very nearly concurrent. The only break in continuity is at the gap described above, and the water-parting here is not more than about two or three miles wide. The last of the Waidina water crossed on the track is 180 feet below the summit of the pass,

\footnotetext{
* Called in error the Navua River in my former paper.
} 
while the bed of the Wainikoroiluva is 270 feet below the same point.

I have very little doubt that, originally, the Waidina and the Navua formed one stream. This may have risen somewhere near the present town of Waivaka, and flowed W.S.W. to the sea; or it may have risen near the source of the present Navua, and flowed E.N.E. to join the ancestor of the Rewa. Of the alternatives, the latter is the more probable. The disturbance in stream-arrangement was almost certainly due to heavy faulting along the line of the Medrausucu Range, and along the course of the Wainikoroiluva and lower Navua, leaving the intervening area as a "horst."

No detailed examination was made of the Waimanu Valley. The river has a remarkably uniform general direction a little north of east, parallel to the Navua-Waidina line just referred to and at right angles to the fault-lines which determine the "horst." Like the Wainivalau and Waidina, it has the character of an antecedent stream, crossing the Medrausucu Range (here rather indefinite) by means of a picturesque watergap. This gap is a very conspicuous feature when viewed from Uvuuvunidavui. I crossed the stream at a point between Vesari and Nabukaluka, and there noted the important fact that granites form a large part of the gravels. From the small size and complete rounding of the pebbles, we see that the outcrops of granite in situ must, probably, be near the head of the stream. This brings the granite area considerably further south than it has ever been observed before. I was informed by natives that it is possible to canoe upstream for some distance from its confluence with the Rewa, but then its course becomes broken up by impassable rapids. These continue for some distance above the point where I crossed it, but then the valley widens out again and the river becomes navigable. This agrees with all the other topographic evidences which point to a very recent origin of the Medrausucu Range.

Summary of Section iii.-The Waidina and Waimanu Valleys are about parallel to one another, and at right angles 
to the Medrausucu Range. This suggests that they occupy lines of weakness (possibly faults) at right angles to the dominant topographic line of weakness expressed by the said range. There is strong evidence for considering both streams as antecedent to the range, and for supposing that the Navua River was formerly continuous with the Waidina. The breaking of connection took place through a heavy fault along the line at present occupied by part of the Wainikoroiluva, leaving a "horst" between that stream and the Medrausucu Range. Most of the evidence for these movements is topographic in character, but is none the less extremely suggestive. The changes must have been very recent. Granite areas are proved to exist as a basement under the Korobasabasaga, and further south at the head waters of the Waimanu.

$$
\text { iv.-Wainivalau Valley. }
$$

I made a journey from Nabukaluka on the Waidina to Narokorokoyawa, our headquarters, along the valley of the Wainivalau. A prospector, Mr. Harding, traversed part of this region, but I was informed that no white man has previously been right across it. Owing to the dangerous nature of the numerous river-crossings (fords they cannot be called) I was compelled to pack up my field book and instruments, and allow a native to carry them. My notes on this portion of the island were therefore written up from memory three days after traversing it.

From the gorge to Nadakuni, the stream hugs the eastern base of the Medrausucu Range; thence it turns eastwards and enters the Waidina just below Nabukaluka. Its bed is not so wide as that of the Waidina, but I believe its volume is nearly as great, a fact already commented on in connection with its probable piracy of the head waters of the Waieliu. It enters the main stream with a very swift current, and at quite a noticeable grade; and as is usual under such circumstances, the bed of the Waidina for some-miles above and below the junction, is very much choked with coarse alluvial deposits. About a mile above Nabukaluka, convex curves of the two streams approach within an eighth of a mile of one another. As the divide is of 
soft soapstone, a junction at this point is, geologically speaking, imminent.

The gorge by which the Wainivalau issues from the mountains is very remarkable, the cliffs rising perpendicularly on both sides almost from the water's edge, for hundreds of feet. Nowhere east of the Medrausucu Range have I found granite or slaty rock in situ, but immediately the gorge is entered highly jointed rocks are encountered, and just to the west of the range granite occurs, in situ, at a level higher than that of the plateau immediately to the eastward, and much higher than the beds of the streams which have dissected that plateau. From this point westwards, the surface of the granitic and slaty rocks is more or less uniform right away to the valley of the Sigatoka. I hold that the existence of a heavy fault along the line of the Medrausucu Range is thus rendered extremely probable, if not absolutely proved; and that the volcanic products of the range have been extruded along this fault-plane. We thus add geological evidence to the topographical evidence for an important fault here.

West of the range is an extensive and well-watered plain, of whose existence few people seem to be aware. For long distances the country is practically level, and no outcrops of rock are met with. Account being taken of the fact that the Wainivalau has had to cut a gorge through the Medrausucu Range, I think it very probable that part, at all events, of this plain has been the site of a lake. No definite evidence can, however, be brought forward. Observation and native information show that, even now, the area is subject to frequent inundation, so that it temporarily takes on a lacustrine habit.

At its western edge this plain rises towards the waterparting between the Wainivalau and Wainimala Rivers, and we pass off soft soil on to solid, much-jointed granite. The stream has entrenched itself deeply in the surface of this rock. The granite is overlain by the lavas and agglomerates of the Uvuuvunidarui Range, which is andesitic in character. The plain is bounded on the south by a ridge of no great elevation; separating it from the Waidina Valley. The granites must have a very 
considerable south-easterly extension as the Wainivobo brings down abundant large granite boulders, and, as already stated, the Waibowa, on the eastern side of the range, has granitic gravels.

The range which bounds it to the north, and of which the Korobalavu is the chief point, is considerably higher than that to the south. The gravels of the Waisomo prove that the granites extend in this direction too.

Rising from the south-western corner of the plain is the aweinspiring mass of Korobasabasaga, with its five towering summits (Plate xiii., fig.1). A more magnificent piece of scenery is beyond the limits of imagination. It rises abruptly, and in places, sheer to a height of nearly 4,000 feet above sea-level, and therefore a good deal over 3,000 feet above the plain. In places there are precipices of quite 3,000 feet. The mass is cleft through its middle, apparently from crest to base, by a stupendous fissure, whose origin I do not at present know. The mountain or rather range has a general S.W. and N.E. extension, and is composed, for the most part, of very massive agglomerates of a very handsome hornblende andesite described in my former paper (p.529). An exactly similar rock is exposed in the left bank of the Wainikoroiluva below Laselase. If the scarp forming this bank is, as suggested, a fault-scarp, the hornblende andesite must be older than the faulting, and therefore probably older than the hypersthene andesites of the Medrausucu Range. This is rather important, as the evidence with regard to sequence of eruptions is so meagre.

In the foregoing sections I have suggested that the plain to the west of the Medrausucu Range represents a "horst" of granitic rock, bounded east and west by two great faults trending S.S.E. and W.N.W. The existence of these faults is, I think, fairly proven by geological and topographical evidence alike, and their very recent date is quite probable. It is also suggested that the ranges of hills bounding the Waidina and Waimanu valleys may be directly due to faulting; on this latter point, however, I do not wish to lay any stress. It is quite likely that 
the ridges, as such, are the normal result of atmospheric weathering. Whether this is so or not I believe the very markedly regular trend of the Navua, Waidina and Waimanu, together with that of the Waiqa and Wainimala, to be described later, points to a very marked direction of weakness along a W.S.W.-E.N.E. line.

It is also conceivable that the topography of the Wainivalau basin may be explained in a different manner. The stream might have worked in a general S.S.E. direction across an elevated plateau. Striking the resistant rocks which now constitute the Medrausucu Range, its vertical corrasion might have been checked there, and have proceeded so slowly that its higher waters working constantly over their available area, kept it in the condition of a slowly sinking peneplain, the rate of sinking keeping pace with the corrasion of the range. It would thus have the character of a superimposed river.

Such an explanation fails, however, to explain the essential geological features, and it is impossible to understand why the stronger Waidina, perhaps fortified by the Upper Navua, should not have excavated an even more extensive plain.

The evidence then is strongly in favour of heavy faulting, with building up of a very recent volcanic range at the fault-plane.

Summary of Section iv. - Hydrographic evidence points to the Wainivalau having very recently been enlarged at the expense of some of its neighbours. Geological evidence points conclusively to the existence of a heavy fault under the Medrausucu Range, whose existence has been suggested before (p.446) for topographical reasons. Possible evidence is adduced to show that the hornblende andesites of Korobasabasaga are older than the hypersthene andesites of Nabukelevu. A possible alternative to faulting, as an explanation of the topographical features of this part of the island, is discussed and rejected.

$$
\text { v.-Waiqa Valley. }
$$

Separated from the Rewa Plateau by the northern part of the Medrausucu Range, and from the Wainivalau Valley by the 
Korobalavu Range, is a very interesting district drained chiefly by the Waiqa, a fairly important tributary entering the Wainimala north of Nacau. Crossing the saddle from Naivucini on the road leading west to Botenaulu and Narokorokoyawa, the track rises over the tuffs, agglomerates, and lavas of Nacau until an elevation of about 675 feet above the Wainimala is reached, and then drops to the valley of the Waiqa. At the summit of the pass there occur great angular boulders of a very remarkable diorite porphyry. In section it is found that this rock is somewhat quartzose and very rich in hypersthene, so that it shows relationship to the more acid members of the charnockite group. The western slope is over decomposed rocks of a similar character in situ. The remarkable nature of the rock was not recognised in the field, and its relationships to its neighbours are therefore obscure and must be left for a future expedition to determine. The level of the Waiqa River is 575 feet below the crest of the ridge. The stream occupies a fairly broad open valley, the most open of any stream of its size which I have seen in the island.

Granite puts in its appearance at a point between Tavua and $\mathrm{Nuku}$; as above explained, the dividing line between this and the charnockite-like rock is not determinate. Some distance west of Tavua the granite is strongly gneissic in character, and associated with this we have a narrow belt of very schistose rock whose relationships are concealed by lack of outcrops.

For some distance west of Nuku the track crosses alluvials, but about two miles west of the town decomposed granite in situ is met with. This rises in high hills which form the eastern boundary of the Upper Wainimala Valley. At the crest of the ridge which separates the Waiqa Valley from that of the Waitabu, the road-level is about 1480 feet above the sea; at the highest point of the range it is at least 200 feet higher than this. In the valley of the Waitabu undecomposed granite is met with in situ, but some distance to the west the rock is apparently slaty; exposures are, however, very poor.

It will be seen that the main direction of the Waiqa is about W. and E., this course being imposed upon it by ranges of 
volcanic material running in that direction. The hills to the south were not visited; those to the north are more basaltic in character than the ranges to the east.

Summary of Section v.-The Waiqa Valley runs east and west for about twelve miles. Considering the size of the stream, it is a very broad and open valley. The rocks exposed are mostly crystalline (granites and schists), but towards the eastern end a remarkable hypersthene rock, with characters linking it to the more acid charnockites, occurs.

$$
\text { vi._Navua-Wainikoroiluva Valley. }
$$

The Navua System is analogous to the Rewa System in that both main rivers keep close to the eastern side of their basins, and draw their waters from wide stretches of country to the west. In both cases there are no important affluents coming in from the east, while very large tributaries enter the right hand bank. This statement is true only if we regard the Wainikoroiluva as the main branch of the Navua System, as I believe it is structurally, though it is certainly inferior in volume to the Navua. On no map of Fiji which I had seen, prior to my recent visit, was the largest stream of the system shown correctly. The information with regard to this portion of the country was supplied by Mr. C. A. Holmes, L.S., Government Surveyor, with the kind permission of His Excellency, Sir Everard im Thurn, and is detailed and accurate.

The structure of the Navua System resembles that of the Rewa in another important particular; the streams in their lower courses are intrenched in a dissected plateau, occupying narrow cañons about 300 feet in depth. The general surface of the plateau is strikingly level, more so than that of the Rewa; from high points in the Namosi district it appears as an almost unbroken plain stretching for miles to the westward. The heights which rise above the general level, such as Koqi, Tuvutau, Nabekalevu, etc., are very strongly suggestive of residuals of at least one older peneplain. The eastern limit of the plateau is sharply defined by the western scarp of the range of mountains, 
of which Nalumu and Nabui are two* of the most prominent peaks.

Reasons have already been advanced for supposing this scarp to have originated in late geological time through faulting. Additional evidence of the same fact is not wanting. Almost as soon as the hill country is entered, in the journey up the Wainikoroiluva, that is, below Naqarawai, ancient-looking tuffs are encountered, and a few miles further on quartz diorites in situ. The "soapstones" to the west of the range are exactly similar to those of the Rewa Plateau, and, like them, are on the whole horizontally bedded. Close to the range the dips depart from the horizontal. Below Laselase the rocks (andesites) in the bed of the Wainikoroiluva are strongly jointed, indicating powerful earth-movement, and the axis of these joints is S.S.E.N.N.W.

The upper portion of the Wainikoroiluva is the only part which I have examined in detail, and this has already been described. $\dagger$ Further examination, on my second expedition, confirms my first impressions as to the comparatively great antiquity of the jointed rocks below Naqarawai. It appears quite certain that there is strong nonconformity between these rocks and the level-bedded soapstones which overlie them. Unfortunately no new section was discovered which throws any important light on the all important question of the relation between the jointed rocks and the quartz diorite immediately to the north.

A considerable extension of the granitic and slaty rocks to the westward is proved by the discovery of well-worn pebbles of such rocks in the Wainimokuta, a large stream entering the Waini-

* The Admiralty chart shows only one very high peak here, and my endeavours to fit in the results of my own magnetic bearings lead me to suspect that Nalumu and Nabui are possibly the names of opposite slopes of the same mountain. The Fijians are very poor geographers, with very little conception of direction and distance, and get hopelessly "bushed" when taken out of their own districts.

$$
\text { † Former paper, p.472. }
$$


koroiluva just above its junction with the Navua. The main Navua was in flood, so that I could not examine its gravels.

The lower portion of the gorge of the Navua differs essentially from that of the Rewa in being a perfect cañon, with perpendicular walls rising straight out of the water. The reason why it has failed to perform any lateral corrasion, as the Rewa has done, is that the materials it has had to excavate have been much harder. The rocks of the Navua Valley are enormously massive andesitic flows, with some interbedded tuffs, while those of the Rewa are soft soapstones. Until it leaves the tableland and begins to open out at the head of the delta, there are practically no enlargements of its valley; while the Rewa and its tributaries are bordered by rich river-flats and flood-plains which sometimes show two, perhaps three, distinct terraces.

One very striking feature of the cañon of the Navua is the existence of numerous "hanging valleys" in its walls. Even the large tributaries, such as the Wainikoroilura, enter the main stream by a series of rapids, that is, not absolutely at grade; while the minor affluents of ten leap from the apparently unbroken bank of verdure of the cañon walls at heights of a couple of hundred feet above the river, making the gorge one of the finest pieces of scenery it has ever been my good fortune to see.

These hanging valleys are, of course, due to the youthfulness of stream-development. Neither trunk nor tributary has yet reached base-level, and the differential erosion of the powerful stream has sunk its bed below the level of its weaker tributaries. Mr. Holmes informs me that similar structures, on an even grander scale, are to be seen higher up the Navua.

Summary of Section vi.-Additional evidence is adduced in favour of faulting having taken place along the valleys of the Navua and Wainikoroiluva. A comparison is drawn between the structures of the Rewa and Navua Systems. Especially it is pointed out that both systems have linear eastern boundaries, and draw their waters from extensive basins to the west. This strongly suggests block-faulting. Additional granitic areas are shown to exist west of those formerly observed. The 
differences in character of the lower Navua and Rewa valleys is explained as due to the difference in hardness of the rocks to be excavated. The incongruity of grade of the Navua and its tributaries, giving rise to hanging valleys, is described.

\section{vii.--Wainimala Valley.}

The upper Wainimala Valley is one of the most interesting and geologically important districts of the island. Up to its junction with the Waisomo* above Vatuvula, and probably for some distance beyond this, it belongs structurally to the Rewa Plateau. Above its junction with the Wailoa to its head, it shows quite a different structure; its banks in this part afford some of the most valuable sections observed at all.

I chose Narokorokoyawa as my headquarters because it lay in the centre of an area of granitic rocks observed by me on my first expedition. I spent a considerable time in trying to determine the relationships of the rock-masses in this region, with very limited success. The jungles here are very dense, and the country very mountainous; exposures are very few away from the rivers, and the problem cannot be considered finally settled.

The plutonic rocks are of two quite distinct types. The first, represented by the Narokorokoyawa granite, $\uparrow$ is a coarse-grained biotite granite, without hornblende, and showing extensive cataclastic structures. The other is represented by the Nadranokula quartz-diorite. $\$$ It is finer in grain than the granite, has hornblende predominant over biotite, and has suffered less than the granite from shattering, possibly because of its lower quartz content.

Associated with, and separating these plutonic rocks, is a band of slaty rock.\| In my former paper I described a type of this

* This is not the Waisomo referred to under Sections i. and iv., but a larger stream flowing into the Wainimala from the north. There are at least three Waisomos in the Rewa System, the third coming from Navunitorilau, and entering the Wainimala at Nasava.

† Former paper, p.501. ‡Former paper, p.506.

\|| Former paper, p.514. 
series, obtained just north of Nasava, as a fine quartzite. It and its associates, extending from Nasava to Narokorokoyawa, are very strongly cleaved, and are, to all appearance macroscopically, slates. My suspicions were aroused on finding that some of the rocks contained porphyritic felspar, and I made an extensive collection in this locality. Microscopic examination of a large number of sections* show that, while many of the rocks vary between actinolitic quartzite and actinolite schist, others are apparently trachytic in structure and composition. Most of these trachytic rocks are strongly silicified and saussuritized, and nearly all show traces of strain. I have etched and stained all the more likely looking ones, but have been unable to detect any nepheline.

It is probable that these rocks represent, not highly altered sediments, as I formerly thought, but bighly metamorphosed trachytic lavas and possibly tuffs. While this is so, the possibility of some sediments being present is not excluded.

This discovery very seriously weakens my previous conclusions as to the great age of the slaty rocks, since it shows that the entire absence of fossils is not due to high antiquity and extensive metamorphism. Nevertheless I claim that all the evidences point to a considerable age for these rocks. They are unconformably overlain by andesitic lavas and tuffs, which have none of the signs of chemical and mechanical alteration so conspicuous in them. They are associated with granitic rocks of coarse grain, and have strain-structures analogous to those found in the granites. The extreme complexity of their jointing proves that they have been subjected to several distinct earthmovements in different directions.

Mawson's discovery of jointed Miocene tuffs $\uparrow$ in the New Hebrides at least suggests the possibility of a similar age for these rocks. The analogy must not, however, be strained too far; he found no trace of granites, while, in Fiji, these cover enormous areas.

* To be described in a subsequent paper.

† These Proceedings, 1905, Vol.xxx. p.446. 
Another band of slaty rock is met with between Botenaulu (called Moira before)* and Waibasaga (called Togicedra before), * and extending some distance northwards. These are even more schistose in appearance than the rocks of the Nasava series; some of them appear in section extremely like some of the felspathic quartzites of the Cambrian rocks of South Australia. Most of them are, however, strongly felspathic and actinolitic, and must probably be classed with the trachytic rocks of Nasava. I attempted to map in the boundaries between these four sets of rocks, but could obtain no definite proof even of their relative ages. They are exposed only at the bottom of the narrow V-shaped river valleys; immediately the hills are mounted one comes upon the level-bedded later volcanic series. In the river-beds and jungle-covered banks I found no sections showing junction-lines between the granites and slaty rocks. The entire absence, even amongst the river-gravels, of quartz porphyries, and the fact that no granitic veins were observed in the field intersecting the slaty rocks, seem to indicate that the granites are older than the slates. On the other hand, there is no definite evidence of trachytic dykes in the granite masses, unless certain small masses near Botenaulu are of such a character.

The general trend of all the members of the older series is about N.N.E.-S.S.W., which also agrees with the direction of dip of the jointed tuffs south of the Udu. $\dagger$ There is no doubt that this area of crystalline and slaty rocks is continuous with those met with in the Wainivalau, Waiqa, and Wailato, $\$$ and elsewhere. The generally even surface presented by these rocks points to their having formed a peneplain. This involves an extensive land surface, powerful earth-movements, and enormous denudation during a protracted period of existence above sea-level, in other words, a continental character for the ancient land. The

* Moira is the name of the district, and Botenaulu is its chief town. Tokikicedra is the name of the rocks actually photographed (These Proceedings, Vol. xxviii. Pl, xxxi. fig.14) opposite the town of Waibasaga.

† Former paper, p.476.

+ Vide infra, p.469. 
surface of the peneplain is everywhere covered with a later unconformable series of more or less level-bedded volcanic products, save where the latter have been dissected away since the last great uplift. In the neighbourhood of Narokorokoyawa the level of the ancient peneplain is only about 300 feet above the river bottom and about 800 feet above sea-level. Southwards at Navunitorilau it rises to over 1,300 feet, and northwards at Rewasau to about 1,100 feet. It must not be forgotten that these and other differences of level are probably due to the tilting accompanying block-faulting.

The Waibasaga, flowing from the west to meet the main stream at the town of the same name, plunges over the edge of the volcanic plateau to the level of the granitic peneplain in three magnificent waterfalls, called Wavou, with a total drop of over 1,600 feet.

In the upper part of the Wainimala Valley, that is above $\mathrm{Udu}$, there seems to be some topographic indication of an older valley-level from 50 to 60 feet above the present stream. There are in places, as near Matainasou, very distinct cut terraces which appear to indicate that the stream cut out a moderately $U$-shaped valley, and then quite recently suffered uplift which caused increased vertical corrasion in the bottoms of such valleys. This is a point which is worthy of further investigation.

Summary of Section vii.-The plutonic and slaty rocks described in my former paper are described in much more detail. It is shown that there are four distinct belts, with a general N.N.E.-S.S.W. trend; and that these form part of an extensive old peneplain, now covered unconformably by more recent volcanic accumulations. Many of the slaty rocks, formerly believed to be sedimentary, are now shown to be slaty trachytes. No evidence is forthcoming to definitely prove the relative ages of plutonic and slaty rocks; the balance of the negative evidence available leans towards the granites being the older. Certain physiographic peculiarities of the valley cutting are referred to, but no explanation of the very extraordinary course of the Wainimala between Nasava and Naivucini is attempted. 


\section{viii.-Wailoa and Nadarivatu District.}

The Wailoa River (Black River, so called on account of the abundance of magnetite sand and limburgite gravel in its bed) is the principal tributary of the Wainimala River. It rises in the southern slopes of Tomanaivi, the highest point in Fiji, and flows in a general S.S.E. direction, joining the main stream just below the town of Udu.

Nadarivatu is situated immediately on the northern edge of the high plateau which extends here within a few miles of the north coast, and in places actually reaches the coast. It lies at an altitude of about 2600 feet above sea-level.

The whole area included in this section is characterised by a remarkable development of extremely basic limburgitic lava, and associated tuffs and agglomerates. These form practically the universal surface-rocks of the district.

Eastwards they pass into the level-bedded "soapstone" tuffs of the Wainibuka. These soapstones, which are gently dipping in places, extend from about Nubumakita right away to the north-east coast apparently. It is extremely probable that they represent the actual extension of the limburgite series, beyond the eastern limit of its solid lavas.

Towards the south the area is bounded fairly sharply by the Wainimala, which, about Udu, suddenly turns east after flowing north for a long distance. The more or less linear boundary of the basic series, corresponding as it does with this sudden change in direction of a main river-valley, certainly points to some major earth-structure; but evidence as to its exact nature is wanting.

Northwards the area reaches the sea at a point north-east of Nadarivatu. To the north-west of Nadarivatu there is a very sharp drop of 2000 feet to the village of Waikubukubu, whence a coastal plain, some eight or nine miles wide, slopes to the mouth of the Tavua River. This coastal plain was described in my former paper (p.478), and it was there inferred from the crateriform shape of the numerous hills which cover it, and from the evidences of extinct hot spring action, that volcanic activity has only comparatively recently died out in this portion of the island. 


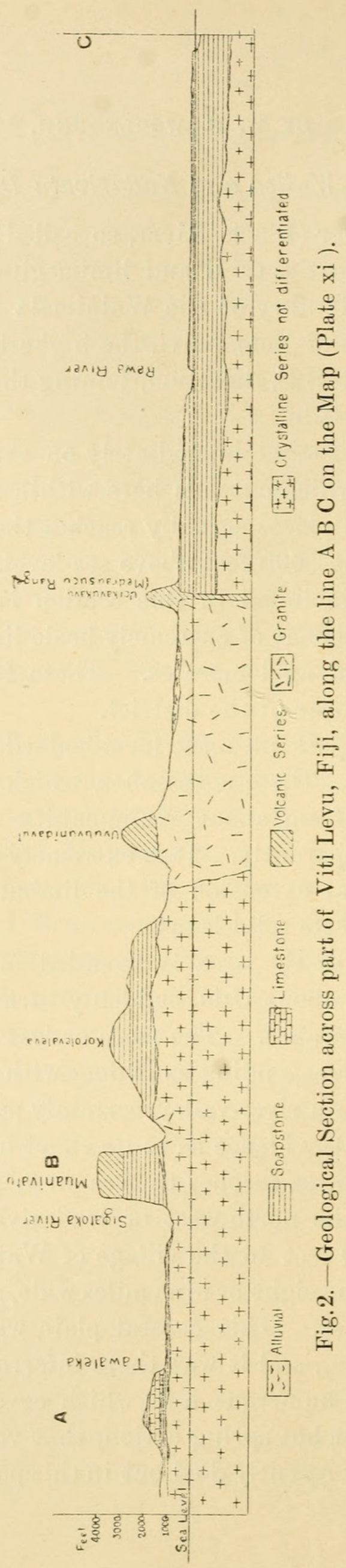


This inference is strengthened by the fact that hot springs do occur in the north-west part of the plain, west of the Tarua River. From what I could make out from rambling native descriptions, these springs, of which there are two sets, must be considerably hotter than those in any other part of the main island, though probably not so hot as those of Savusavu Bay in Vanua Levu, described by Guppy.* I understood that the water was at times hot enough to severely scald one. The flow appears to be spasmodic and, the natives stated, sometimes violent.

In my former paper I suggested the possibility of a fault bounding the Nadarivatu scarp. $\dagger$ Most of my correspondents have taken my statement to mean that such a fault had definitely been proved to exist. I did not intend such an impression to be created; even at the time I regarded the existence of such a fault as highly problematical, and further investigations have shown that no such fault exists in this place. I have now no doubt that Dr. Guppy's explanation $\ddagger$ of this plain as a recently elevated plain, chiefly of marine accumulation, is the correct one.

Westwards, the area extends at least as far as the Sigatoka River at Nadrau. Sections of the columnar andesite exposed there, and formerly described as an augite andesite, show that the rock is much more basic than was supposed, a limburgite in fact, very similar to the Nadarivatu rock but more basic. The strong curvature and divergence of the columns indicates that the cooling surface in contact with the rock was irregular. There are two flows separated by a bed of fine tuff. The lower one rests on a coarser tuff containing beautifully perfect augite crystals, and recognisable remains of marine organisms.

The most interesting feature of the area under consideration is the shell-bearing conglomerate at Nasoqo, previously described.§

* Guppy, H. B., “ Observations of a Naturalist in the Pacific," etc., 1903. Vol.i., p.25.

+ loc. cit., Plate xxxiv.

$\ddagger$ Private communication.

$\S$ Former paper, p.477. 
I revisited the locality, and searched it as well as very adverse conditions would allow. Although no fossils better than those before obtained were collected, my previous work is confirmed in every particular. It will be shown later (p.468) that the granite floor has been met with, in situ, at a point only a little to the south of this, and can lie at only a very slight depth below the Nasoqo conglomerate which is, therefore, in all probability a basal conglomerate. As it lies at an altitude of 790 feet above sea-level, the uplift during Cainozoic time must have been at least that amount.

The level-bedded tuffs associated with the limburgite series reach an elevation of over 4000 feet. From their great uniformity of composition and their persistence, they must certainly be marine, for it does not seem possible to obtain such uniformity and level bedding in a subaërial formation. If this is so, the elevation during Cainozoic time must have reached at least 4000 feet.

If the tuffs are marinæ, then their associated flows must also be submarine, and yet they extend with perfect uniformity over very wide areas. The only very vesicular lavas met with are north of Udu, and north of Nagatagata on the Sigatoka.

Another conglomerate, similar in many respects to that at Nasoqo, occurs below the village of Dubuya south of Nadrau. It does not seem to contain any fossils, and I found no pebbles other than andesitic ones in it. It is, however, related to the older rocks below Waisa.

Summary of Section viii.- The rocks of this district are essentially level-bedded soapstones, with intercalated limburgites. These are all certainly of marine origin, and, since they rise to over 4000 feet above sea-level, point to an uplift of at least that amount in Cainozoic time. A basal conglomerate containing granite pebbles and resting on a floor of granitic rocks (exposed a little distance to the south) is met with at Nasoqo on the Wailoa. In it occur marine shells, including Conus. These are too poorly preserved for specific determination, but are certainly Cainozoic. Shells (Pecten, etc.) and corals (Goniophyllum) also 
occur in a tuff below the main limburgite at Nadrau. Another conglomerate occurs south of Nadrau, but does not contain granite pebbles nor fossils. It is, however, probably the base of the limburgite series.

Passing eastwards, the solid rocks disappear, leaving only the tuffaceous members of the series.

The fault at Nadarivatu whose possible existence was suggested in my former paper, does not exist. Hot springs occur near Tavua, bearing out the suggestion that volcanic action has been very recent in this part of the island.

\section{ix.-Muanivatu District.}

This district lies in the Sigatoka Valley, just about the junction of several large tributaries with the main stream. I have taken the liberty of calling the district after the noble mountain peak, over 4000 feet high, which is its most conspicuous feature.

This area is of very great geological importance, on account of the sections afforded of the older rocks, and the possibility that some of these sections may show the relationship of these rocks to fossiliferous formations. The district is well worthy of a separate expedition. I was prevented from returning to it on account of floods. Among the points of special geological interest may be mentioned the wide area of granite and associated rocks of the Wailato, Waivou, Wainasa valleys; the slaty rocks of Namoli* and the district immediately to the north, the hot springs of Waibasaga, the granite-bearing agglomerates of Nukuilau, the cave-limestones of Tawaleka, the level-bedded soapstone of the higher parts of the district, and the magnificent volcanic mass of Muanivatu itself.

My former traverse indicated that no granitic rocks outcrop in the valley of the main stream of the Sigatoka, though granitic pebbles are abundant, particularly below Waibasaga. At this town a large tributary, the Wailato, comes down from the east. At a point only a mile or so above the junction, the granite is 
met with in situ. It nowhere rises much above the level of the stream, and is capped by rocks of the later volcanic series. It is associated with strongly jointed andesitic rocks. The Wailato is only one of a series of rivers rising in the neighbourhood of Muanivatu; and in the other streams, at all events in the Waivou at Nakoro, and the Wainasa above and below Naduta, similar granitic rocks occur, with the same relationship to streamdevelopment as that noted above. We have, therefore, a wide extent of these older rocks brought to light in this district, at or about the same level as those in the Wainimala, Wainivalau and Waiqa Valleys, and, like them, retarding the vertical corrasion of the rivers. The two sets of exposures are certainly continuous beneath the overlying volcanic series, so that a great area is indicated for the granitic series.

The slaty rocks of Namoli were inaccessible owing to flood, but the discovery of granite in situ so close to the south-east is an argument in favour of the considerable age of the slaty rocks. The hard, green, jointed tuffs* south of Waisa $\uparrow$ certainly belong to the same series.

The hot springs at Waibasaga on the Sigatoka, like those of Naseuvou on the Waidina, occur close to what appears to be the edge of the granitic area, or, rather, close to a spot where that area is brought to the surface, possibly by faulting.

At the town of Nukuilau an interesting and important section occurs. Just west of the town is a small creek in whose bed large boulders of granite occur. It is, however, somewhat doubtful whether granite occurs in situ in the watershed of this creek. A road-cutting close by shows a series of tuffs containing large rounded boulders of granite in abundance, and this may be the immediate source of the boulders in the creek. The granite is relatively more abundant than in the Nasoqo conglomerate, but in the Nukuilau beds fossils do not seem to occur. The section is nevertheless confirmatory of the Nasoqo section as

* Former paper, p.480.

† Possibly the name of the district and not of the town. 
indicating the lapse of an enormous period of time between the injection of the granite and the formation of the tuff.

The cave limestone of Tawaleka is considerably folded, the contortion being connected with that of the tuffs further down the river. The latter were not visited during my second expedition.

A splendid view of a mountain called Nasikawa, east of Natuatuacoko, is obtained from the hills north of Tawaleka. From this distance it appears to have the structure of a mountain composed of dipping beds of varying hardness, dip slopes and scarps being recognisable. The dip is about W.N.W. at $40^{\circ}$.

Most of the higher points in the district are composed of levelbedded soapstone. This is met with unconformably overlying the slaty rock at Namoli, and there attains an altitude of fully 1,500 feet above the river-bed, and about 2,100 feet above sealevel. A similar material occurs unconformably (?) overlying the cave limestone at Tawaleka.

The top 1,000 feet, or thereabouts, of Muanivatu, consist of a mass of columnar pyroxene andesite. It is possible that this may be a sill, but it is more probably a flow. It yields magnificent precipices.

Summary of Section ix. - This district, lying not far from the head of the navigable water of the Sigatoka, was so far removed from my base that I have not yet explored it thoroughly. While in the district, meteorological conditions were extremely unfavourable. I have seen enough, however, to prove that the energies of any future expedition should be concentrated on the solution of the many problems presented by it.

Granitic rocks do not occur in the bed of the main stream, but highly jointed, ancient-looking tuffs and slaty rocks form the bed, from about Waisa at least to Koroilevu. Granites and related rocks are extensively exposed in the group of tributary streams which meet the main river between Namoli and Waibasaga. These are about the same general altitude as the granitic rocks of Narokorokoyawa, and undoubtedly form part of the ancient peneplain referred to under Section vii. of this paper. A granite-bearing 
conglomerate occurs at Nukuilau, proving that granites were exposed at the surface at the time when the bottom beds of the tuffaceous series were being deposited. This tuffaceous series reaches a thickness of at least a couple of thousand feet, and is level-bedded and almost certainly marine. It is probable that the cave limestone of Tawaleka is part of this series, though it is by no means impossible that it may be portion of an older series. There are beds of tuff (?) east of Natuatuacoko, dipping W.N.W. at high angles; their relationship to the limestones and granites remains to be discovered. The upper portion of Muanivatu consists of an enormous mass of pyroxene andesite.

\section{x.-Navosa Plateau.}

This district lies at a very uniform height of 3,000 to 3,500 feet above sea-level. It stretches from the Wainimala on the east, to the Sigatoka on the west. Southwards it is bounded by the deep valleys south of Muanivatu and Korolevaleva. Northwards it runs into the higher portion of the Nadarivatu Plateau, which culminates in Toma na Ivi at 4,555 feet.

Both east and west slopes are extremely steep. As noted above (p. 458), a considerable river plunges over its eastern scarp, and forms the magnificent falls of Wavou, near Waibasaga on the Wainimala. Throughout the greater part of its extent it consists of level-bedded soapstones which, for reasons given above, I consider to be of marine origin. Only in the lower portions of its eastern scarp are solid rocks met with. Here there are pyroxene andesites resting on granite. Its western scarp, forming the left bank of the Sigatoka gorge at Namoli, is composed of soft, greasy, level-bedded "soapstone" almost down to river-level. Only at two points on the surface of the plateau were solid rocks encountered, and these were certainly parts of the Muanivatu mass just described. Almost the whole surface is a hideous morass.* It is drained (!) by

* I strongly advise anyone intending to cross this plateau to do so either from Nadrau to Rewasau, or from Naduta to Nasava, viâ Korolevaleva. These tracks are both bad, but nothing like so bad as the dreadful one from Namoli (or Tavua) on the Sigatoka to Waibasaga on the Wainimala. 
a number of streams of fairly considerable volume. Towards its south-west corner these streams flow into the Sigatoka, but throughout the greater part of its extent the drainage is towards the Wainimala. Thus the Sigatoka, along part of its course at all events, like the Navua and Rewa, keeps close to the eastern margin of its watershed. The apparent exceptions to this general rule are almost certainly due to piracy of Wainimala water by branches of the Sigatoka in the Muanivatu area.

The plateau, though rather barren geologically, is an extremely important topographic feature. It has a powerful effect upon climate and rainfall, and on the distribution of the flora of the island. To the east, we have the heavily forested country and bamboo jungles of the Rewa and its tributaries; to the west, the rolling hills of the Sigatoka and $\mathrm{Ba}$, covered with a jungle of reeds about 8 to 10 feet high. The surface of the plateau is densely wooded, but the downward limit of forest trees on the western side is extremely sharply defined, and forms a most remarkable "timber line." It has also had a powerful influence on the migration of the Fijian tribes; the people on opposite sides of the range belong to quite distinct types.

Summary of Section x. - The Navosa Plateau separates the Wainimala and Sigatoka Valleys, and rises to an average height of over 3,000 feet above sea-level. On both east and west it is bounded by steep escarpments. It is almost entirely composed of level-bedded soapstones, which on the eastern side overlie, and on the western underlie, andesitic rocks. Below the falls of Wavou on the east, the andesites overlie the granitic rocks of the Narokorokoyawa series. It is an extremely important feature in determining the distribution of climate, rainfall, vegetation, and races of men.

\section{xi.-Nadrau-Rewasau Section.}

This belongs structurally to the Navosa Plateau, but I have separated it to call special attention to two very important occurrences. One is the section at Nadrau on the Sigatoka, the other that at Rewasau, in the Wailoa Valley. 
The former has already been described.

North-west of Rewasau the surface of the plateau consists of a veritable "clinker field" of very basic lava. This rests on a series of several hundred feet of level-bedded soapstones. Then comes a thick and very massive agglomerate or conglomerate bed resting directly upon an irregular surface of granite. This is the only place, so far as I know, where the actual junction-line can be seen between the conglomerates at the base of the soapstone series and the pavement rocks. This point is within two or three miles of Nasoqo, where the granite-bearing fossiliferous conglomerate occurs, but at the latter place the pavement rocks are not exposed. The Bualevu conglomerate of the Sigatoka underlies the fossiliferous tuffs and basic lavas of Nadrau in almost identically the same way as the similar formation under consideration. At Bualevu the conglomerates are not far removed from the jointed tuffs of Waisa, which may have formed their surface of accumulation, but no junction-line is seen.

Between Rewasau and Nadrau the greater part of the track crosses level-bedded soapstones. In several places, however, there are exposures of considerable extent of andesitic rock. There are also patches of much-jointed rock which may represent inliers of the older series.

$\mathrm{Summary}$ of Section $\mathrm{xi}$.- The chief point of interest in this district is the highly interesting and important section at Rewasau, showing a coarse conglomerate resting on the denuded surface of a mass of granite. This is certainly the same formation as has been met with at Nasoqo and is in all probability continuous with a similar conglomerate at Bualevu on the Sigatoka. Both the latter occurrences have Tertiary fossils associated with them.

\section{General Summary of Results.}

The greater portion of the island of Viti Levu is covered by a thick series of level-bedded "soapstones," which I believe to be marine redistributed tuffs. In places, as in the Nadarivatu District, thick flows of limburgitic lava are interbedded with the 
soapstone. Elsewhere, as at Suva and at Tawaleka, we have interbedded fossiliferous limestones, certainly of Tertiary age. These rocks form what I have somewhat loosely termed the "Newer Series." They lie unconformably upon a much older series of rocks, amongst which granitoid rocks predominate. With these are associated extensive areas of rocks with highly perfect and very complex slaty cleavage developed in them. These were formerly believed to be altered sediments, but later investigations have proved that in many, if not most, cases they are highly metamorphosed volcanic materials, in part trachytic. That they are much older than the newer series is proved by the very marked lithological differences, by their universally inferior position, and by the occurrence of pebbles of granite and other rocks in massive beds of conglomerate at Nasoqo on the Wailoa, Rewasau on the Wailoa, and Nukuilau on the Sigatoka. All these places are at, or very near, the junction of the "Newer Series" with the older series. At Bualevu on the Upper Sigatoka there is another conglomerate on probably the same geological horizon, but no granites have been found in it. At Nosoqo, and at Nadrau (near Bualevu) fossils have been found which show that the beds in question belong to some part of the Tertiary era, though their preservation is not good enough for specific determination. We have, nevertheless, the very important conclusion that basal conglomerates of a great Tertiary series rest unconformably upon, and contain pebbles of, an enormously older series made up of granitoid and slaty rocks.

So widespread is the newer series that it is only where extensive denudation has removed it locally, that the older series is exposed to view. We therefore meet with the older rocks chiefly in the bottoms of the narrow, young river-valleys. In such positions they have been met with in situ in the Wainivalau, Wainimala, Wailoa, Sigatoka, Wailato (and neighbouring streams) and Wainikoroiluva Rivers. Their presence is inferred from river-gravels in the Waimanu, close to the Waidina, and in some of the north-west branches of the Navua Rivers. In one place only, so far as I know, do they occur extensively forming the 
main water-partings of the island, namely, at Navunitorilau, between the heads of the Wainikoroiluva and Wainimala Rivers. Their existence as a basement has been proved over an area of at least 35 miles by 30 miles. It is inferred that their surface was, prior to Tertiary time, reduced to the condition of a peneplain.

The most recent rocks (excluding the present-day river-alluvials and the coral-reefs) appear to be a series of andesitic volcanics varying from pyroxene andesite to hornblende andesites. It is likely that, of the two, those of hornblendic facies are the older. These andesitic rocks form lofty mountain masses, and yield magnificent scenic effects. They have, in part at all events, been extruded along major fault-planes, which have had a dominant influence on the structural features, and even on the very existence of the island of Viti Levu and of the Fiji Group as a whole.

$\mathrm{Faulting}$.- - One very important line of faulting is shown to exist, in a general N.N.W.-S.S.E. direction, along the course of the Medrausucu Range; a parallel line is inferred, with great probability, to exist along part of the courses of the Wainikoroiluva and Navua Valleys. The country between these two faults is of the nature of a "horst."

A second axis of faulting about at right angles to the first is suggested, but the evidence for its existence, resting as it does solely on topographical evidence, is not so convincing as that for the other axis.

$\mathrm{U} p \mathrm{l}$ if $\mathrm{t} \mathrm{s}$. - The basal beds of the newer series reach an altitude of 1350 feet above sea-level near Nadrau; the granitic rocks attain about the same level at Navunitorilau. The topmost beds of the level-bedded soapstones reach well over 4000 feet, and probably the rocks (limburgites and tuffs) forming the highest summit in the island (Toma na Ivi, 4555 feet) are members of the same series. The soapstones are certainly marine beds, and we thus have evidence of a positive movement of the land, during Cainozoic time, amounting to well over 4000 feet. Further investigation is necessary to completely trace the stages of this 
elevation. It is certain that it was a differential movement. The levels of the highest beds of soapstone and of the basal conglomerates of the newer series agree in pointing to a general tilt towards the south-east.

River-development points to the same conclusion, since the three great river-systems of the Rewa, the Navua, and the Sigatoka have markedly asymmetrical drainage-trees, drawing their waters almost entirely from the northern and western portions of their basins. The exceptions to this rule, which are most marked in the case of the Sigatoka, are believed to be explicable as a result of river-piracy on a large scale. The Sigatoka has probably been robbed by the $\mathrm{Ba}$, but has enriched itself at the expense of the Wainimala and probably of the Navua.

It is possible that the original tilt was towards the E.N.E., but more probably the marked trend of several of the chief streams in that direction has been determined as a result of the faulting explained above. It will be seen that the rivers have a marked tendency to a rectangular arrangement along general E.N.E.-W.S.W., and N.N.W.-S.S.E. lines. It is believed that this tendency has been imposed upon them by block-faulting of the land. The suggestion is made that the upper Navua and Waidina Valleys were at one time continuous, but have been cut off by the fault along the Nalumbu-Nabui Range.

The rivers are all in a condition of youthfulness. They are for the most part still engaged in sinking deep narrow cañons in the surfaces of otherwise level plateaux. In the case of the Navua River the drainage-system is so immature that its tributaries do not meet it at grade, and the smaller ones form veritable hanging valleys. This immaturity is partly due to the hardness of the rocks through which the beds have to be sunk, as compared with those in the Rewa and Sigatoka Valleys. Both the latter streams have progressed considerably towards maturity, as the "falls-line" on the Rewa has receded a very long way, and the stream has, within the present cycle, built a large delta. 
There is abundant evidence, particularly in the Rewa Valley, that the earth-movements have been chiefly positive, and that they are probably still in operation. There are remains of older delta-deposits about the head of the present delta, and about 200 feet above its level. This intermittent, but probably not oscillatory, uplift may account for the entire absence of lakes in such a youthful topography. The only possible evidence of lakes is in connection with the Wainivalau Valley. This stream was probably temporarily dammed by the elevation of the Medrausucu Range.

Most, or all, of the streams flowing across the trend of this range are excellent examples of "antecedent rivers." In the case of the Waieliu (Former River) there seems to be a suggestion of river-capture having taken place on a large scale within. historic time.

The rivers of the north-west have not been critically examined, but their distribution shows that there is a very fine field there for physiographic research.

\section{Conclusion.}

The accumulation of evidence, both of a geological and of a geographical nature, while it points to certain mistakes in detail in my former work, on the whole strongly bears out the conclusions arrived at in the paper presented to this Society about four years ago.

The great extension of granitic and slaty rocks, their baselevelling to form a peneplain, their relatively great age, as proved by the occurrence above them of basal conglomerates of Tertiary age, and the occurrence of very heavy systematic faulting, all lead towards the conclusion that Viti Levu, and therefore probably the whole of Fiji, has been a land-area for enormous periods of time, even reckoned geologically. It has had sufficient magnitude and durability to permit of earth-movements competent to produce schists: it has existed so long as a land-surface that large rivers have had time to reduce it to base-level. These facts constitute in my mind the essentials of a continental area. Its relationships to the surrounding continental masses have been 
fully discussed in my former paper, and the mechanism of separation, namely faulting, was there suggested. In this paper it is shown that some faulting, at all events, has occurred.

I am therefore compelled to respectfully differ from Dr. Guppy* in his general conclusions as to the origin of Vanua Levu. He believes that the second island of the group is essentially an oceanic island, built up from great ocean depths, and that it has never formed part of a great continental mass. Its axis is parallel to the second line of faulting I have suggested for Viti Levu, and the whole of the structure lines of the group strongly suggest that the archipelago is essentially a unit built upon the axes which I have postulated for the main island.

The absence of granitic or slaty rocks on Vanua Levu may possibly be explained by the fact that its rivers, not being so powerful as those of Viti Levu (I do not speak here from personal experience) have not as yet succeeded in reaching and laying bare the basement rocks.

With his reading of the later portions of the geographical history, I am in agreement, particularly as regards the general upward movement of the land. No student of Island geology can fail to be indebted to his painstaking labours for many valuable suggestions, even if he cannot share with him all his conclusions.

In conclusion I beg to again point out that a most fascinating field for study lies almost at our doors. The work is of interest and importance to the biogeographer as much as to the geologist, and I sincerely hope that Australian men of science will not rest till the secrets of this wonderful land have been completely laid bare.

Postscript (added 16th August, 190\%).- - I have lately received from the Rev. - Lelean, of Nailaga, a suite of specimens illustrating the gravels of the $\mathrm{Ba}$ River. They contain no trace of granite rocks, so that the older series cannot outcrop extensively in the area drained by that river.

* "Observations of a Naturalist in the Pacific." London. 


\section{EXPLANATION OF PLATES XI.-XV.}

Plate xi.

Geological Sketch Map of Viti Levu, Fiji.

Plate xii.

Map of Viti Levu, Fiji.

[Note.-The gaps in the last two syllables of the name Warnikoroiluva (just above the name $\mathrm{NABUI}$ ) represent the missing letters $\mathrm{L}$ and $\mathrm{v}$.]

Plate xiii.

Fig.1.-Korobasabasaga from the east. Nearly 4,000 feet above sea-level. Native name means "the mountain with the much divided summit." It represents the denuded remnant of a line of volcanic cones along a N.E. and S.W. axis. The summits consist of solid necks of hornblende-andesite agglomerate, and were probably amongst the earlier Cainozoic volcanoes.

Fig. 2.-Voma, a volcanic peak at the head of the Waidina River. It is composed essentially of hypersthene-andesite agglomerate, and is probably amongst the latest of the Fijian volcanoes.

Plate xiv.

Fig.1.- Nabui, another hypersthene-andesite peak on the Wainikoroiluva River. It probably belongs to the same suite of eruptions as Voma, and is later than Korobasabasaga, which lies a little to the northeast. The precipitous fall in the picture is about 2,000 feet high, and may be the direct result of faulting.

Fig.2.-Upper Waidina Valley, showing that the stream has in places passed the period of extreme youth, though it is still quite young. The forms of the mountains in the background strongly suggest blockfaulting.

Plate $\mathrm{xv}$.

Figs.1-2. - Sections of upraised (Tertiary) coral reef exposed in road-cutting behind the hospital, Walu Bay, Suva. The "reef channels," characteristic of present-day reefs, are filled in with "soapstone," which also covers the limestone. Photographs by C. A. Holmes, Esq., Suva. 


\section{$2 \mathrm{BHL}$ Biodiversity Heritage Library}

Woolnough, W. G. 1907. "A contribution to the geology of Viti Levu, Fiji." Proceedings of the Linnean Society of New South Wales 32, 431-474. https://doi.org/10.5962/bhl.part.19576.

View This Item Online: https://www.biodiversitylibrary.org/item/30115

DOI: https://doi.org/10.5962/bhl.part.19576

Permalink: https://www.biodiversitylibrary.org/partpdf/19576

\section{Holding Institution}

MBLWHOI Library

\section{Sponsored by}

MBLWHOI Library

\section{Copyright \& Reuse}

Copyright Status: NOT_IN_COPYRIGHT

This document was created from content at the Biodiversity Heritage Library, the world's largest open access digital library for biodiversity literature and archives. Visit BHL at https://www.biodiversitylibrary.org. 